\title{
Research on Roles Transformation of Stakeholder in the Industry Chain of Industrialized Building in China Based on Niche Theory
}

\author{
Yuedan $\mathrm{Liu}^{1}$, Chao Mao ${ }^{1 *}$, Guiwen $\mathrm{Liu}^{2}$, Fangyun $\mathrm{Xie}^{3}$ and $\mathrm{Yan}_{\mathrm{Fu}}^{4}$ \\ ${ }^{1}$ MS, School of Construction Management and Real Estate, Chongqing University \\ ${ }^{1}$ Associate Professor, School of Construction Management and Real Estate, Chongqing \\ University \\ ${ }^{2}$ Professor, School of Construction Management and Real Estate, Chongqing University \\ ${ }^{3}$ PhD, School of Construction Management and Real Estate, Chongqing University \\ ${ }^{4}$ Associate Professor, School of Construction Management and Real Estate, Chongqing \\ University \\ *Corresponding author's e-mail: maochao1201@126.com
}

\begin{abstract}
Construction industrialization plays an important role in the development of construction industry, and the stakeholders of the industrial chain are the key factors affecting the development. Therefore, the purpose of this paper is to study the transformation of stakeholders in the construction industrialization industry chain from the perspective of niche theory. Through the method of literature review, the enterprise niche measurement model is studied and established. Then take the case of 59 national housing industrialization base as the verification goal, explore the change law of stakeholders. The results show that the transformation situation of various stakeholders is quite different and related to the Division of labor in the industrial chain.
\end{abstract}

\section{KEYWORDS}

Niche Theory; Industry Chain of Industrialized Building; Roles Transformation of Stakeholder

\section{INTRODUCTION}

As present, the sustainable development of the construction industry and the transformation and upgrading of the traditional construction industry have received wide attention, and building industrialization is an important way to achieve sustainable development in the construction industry(Ji et al. 2013).At present, however, the development of building industrialization in China is still in the bottleneck stage, facing many problems such as imperfect local policies, incomplete technical system, low market awareness, incomplete industrial chain, high initial cost, lack of industrialized workers and experienced related management personnel(Xiao et al. 
2015; Zhai et al. 2014; Zhang et al. 2014).Among them, the emergence of new roles and stakeholder relations in the construction industrialization industry chain has led to more uncertainty( $\mathrm{Li}$ et al. 2016). These uncertainties seriously hinder the efficiency of the development of building industrialization. Therefore, traditional construction enterprises need to understand how to consider the role transformation in the industrial chain in the process of transformation, in order to ensure that they choose a relatively better way to achieve their corporate goals, thus promoting the development of the entire building industrialization system. Therefore, at this stage, it is necessary to understand the changing law of the role of stakeholders in the construction industry chain.

\section{REVIEW OF PREVIOUS WORK}

Nicheis an important and abstract concept in modern ecology(Qian and Ren 2006). According to the bionics principle of enterprise, the niche theory is introduced into the enterprise management and management, which has the theory of enterprise niche(Qian and Ren 2006). As a branch of enterprise ecological theory, it appeared gradually in the field of enterprise management in the early 80 of the late 1970s(Qian 2005). Although after years of research and development, the concept of "enterprise niche" itself has not yet formed a unified understanding, there are two main points of view, respectively, Hannan and Freeman (1977) to represent the "macro niche" and to Baum and Singh (1994) as the representative of the "microniche" two views. However, because this research is based on the research object, the nature of the research object determines that the concept adopted in this paper belongs to the "macroscopic niche" proposed by Hannan and Freeman. At present, many research work has carried on the preliminary research to the enterprise niche characteristic, the structure, the modelling method and so on, and has applied and expanded to the enterprise strategy, the organization competitiveness appraisal, the enterprise sustainable Development competition mechanism and so on many aspects.

The proposal of the enterprise niche reflects that the researchers begin to break through the view limit of the enterprise as an isolated individual, and pay more attention to the coordination and symbiosis between enterprises and the surrounding environment (Guo and $\mathrm{Xu}$ 2009). Enterprise niche is usually measured by a series of indicators, such as enterprise niche dimension, width, overlap and density, these concepts are the basis of niche overlapping and separation theory(Guo and $\mathrm{Xu} 2009$ ). At present, there are many researches on the application of enterprise niche measure to the competitiveness research among enterprises ( $\mathrm{Lu}$ and Lin 2013; Sun et al. 2017; Zhao and Tang 2016). However, no research has been carried out on the application of enterprise niche measure in the research of enterprise transformation, this research attempts to use it for the transformation of various stakeholders in the industrial chain of building industrialization.

\section{METHODS}

In this study, two problems should be solved: 1) How to establish the model of the role transformation measure of the stakeholders in building industrialization according to the niche 
theory. 2) How to find out the law of stakeholder's role transformation according to the case study. Figure 1 shows the methodology used in this research.

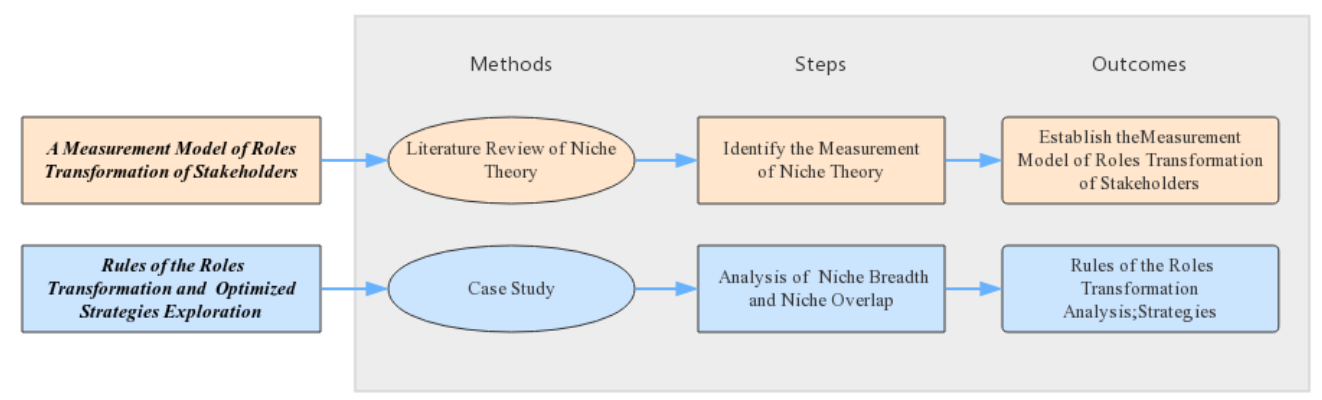

Figure 1. Method Framework

\section{A MODEL OF STAKEHOLDER ROLE TRANSFORMATION MEASUREMENT}

In order to quantitatively describe and analyze the law of the transformation of stakeholders in the industrial chain of building industry, the corresponding econometric models should be set up to measure and evaluate. This research will select the most suitable niche measure method from the research of the niche measure theory through the literature review method, as the data analysis model of this research. The concept of niche is abstract and fuzzy, what can give people specific understanding is some of the quantitative indicators that describe it, namely the socalled niche metrics, which includes niche breadth, niche overlap, niche volume and niche dimension, and niche width and niche overlap are important indexes to describe the relationship between niche and niche of a species ( $\mathrm{Li} \square$ et al. 2003).

\section{Enterprise Niche Breadth}

Enterprise niche width refers to the sum of all kinds of market resources and environments that are used by an enterprise, that is, the degree of diversification with market resources(Zhang and Guo 2009). Based on the characteristics of the enterprise niche theory and the assembled construction enterprise, this paper defines the "niche of the assembled building enterprise" as the multidimensional space resource occupied by the assembled construction enterprise in the market, and the "niche dimension" indicates the number of factors influencing the effect of the assembled construction enterprise. The niche width means that the prefabricated construction enterprises are adaptable to a large area and the niche is narrow. "Niche overlap" can be used to characterize the similar degree of niche between prefabricated construction enterprises, and the competitive strength of enterprises is generally proportional to the niche overlap.

In view of the niche width can be used to describe the breadth of enterprise use of resources (Hannan and Freeman 1977), the prefabricated construction Enterprise "niche business width" (Pij) can be used in the transformation of traditional construction enterprises in the number of business after the transformation of the proportion of the number of all business, the ratio to express, That is to reflect the degree of diversification of the resources occupied by the assembled construction enterprises in the market. In the theory of ecology, many scholars put 
forward the model of ecological niche width measure, according to the niche theory and its measure research, which are summarized by $\mathrm{Li} \square$ et al. (2003), and so on, the typical measure formula of niche width has Simpson formula and Levins formula, outside also has Petraitis formula, Schoener formula, Smith formula, Yushio Park type and so on. Based on the characteristics of the research object, this paper selects the Simpson formula which is widely accepted and widely used in the industry to measure the niche width of the assembled construction enterprise, as shown in the formula (1), and the variable description is shown in the table 1 .

$$
\mathrm{NW}(s) j=1-\sum_{j=1}^{r} p \mathrm{ij}^{2} \quad i, j=1,2, \ldots, n
$$

Table 1. Description of niche width variables for assembled construction enterprises

\begin{tabular}{cc}
\hline Variable & Definition \\
\hline$N W_{(s) i}$ & $\begin{array}{c}\text { Simpson niche breadth of the i-type enterprise } \\
\text { Category i enterprises after the transformation of the number of } \mathrm{j} \\
\text { business as a proportion of the total number of business after the } \\
P_{i j}\end{array}$ \\
transition \\
Number of business
\end{tabular}

\section{Niche Overlap}

Enterprise niche overlap is the degree of the same niche factors and niche similarity between enterprises, which can be used to characterize the degree of market competition. It is generally used to characterize the degree of competition. The greater the degree of niche overlap, the more competitive the enterprises are facing(Lu and Lin 2013). The niche overlap degree of the assembling type construction enterprise refers to the degree of niche similarity of the assembled construction enterprise, which can be expressed by the similarity of the business quantity in the different business distribution after the transformation of the traditional construction enterprises. In this paper, the niche overlap index of cowll and Futuyma (Guo and Xu 2009) proposed by the application scope is selected, and the variable description is shown in figure 2 . The niche overlap Index range is $0 \sim 1,0$, which indicates that the niche is completely separated, and 1 indicates the niche overlaps completely.

$C i k=1-\frac{\sum|N i j / N i-N k j / N k|}{2}=1-\frac{\sum|p i j-p k j|}{2} \quad i, j=1,2, \ldots, n$ 


\begin{tabular}{|c|c|}
\hline Variable & Definition \\
\hline$C_{i k}$ & $\begin{array}{c}\text { Cow11 \& Futuyma Niche overlap Indices between Class i enterprises } \\
\text { and Class } k \text { enterprises }\end{array}$ \\
\hline$N_{i j}$ & Number of $\mathrm{j}$ Business after transformation of category $\mathrm{i}$ enterprises \\
\hline$N_{i}$ & The number of all businesses that have been transformed by class $i$ \\
\hline$N_{k j}$ & Number of $\mathrm{j}$ Business after transformation of Class $\mathrm{k}$ enterprises \\
\hline$N_{k}$ & $\begin{array}{l}\text { The number of all businesses that have been transformed by category } \\
k \text { Enterprises }\end{array}$ \\
\hline$P_{i j}$ & $\begin{array}{l}\text { Category } i \text { enterprises after the transformation of the number of } j \\
\text { business as a proportion of the total number of business after the transition }\end{array}$ \\
\hline$P_{k j}$ & $\begin{array}{l}\text { The proportion of the number of } \mathrm{j} \text { business after the transformation of } \\
\text { category } k \text { enterprises to the number of all operations after their } \\
\text { transformation }\end{array}$ \\
\hline$r$ & $\begin{array}{l}\text { The proportion of the number of } j \text { business after the transformation of } \\
\text { category } k \text { enterprises to the number of all operations after their } \\
\text { transformation }\end{array}$ \\
\hline
\end{tabular}

Figure 2. Description of niche overlap variables in assembled construction enterprises

\section{EXPLORATION OF OPTIMIZED STRATEGIES: CASE STUDY}

This paper obtains the data through the case analysis, and carries on the case analysis to the end of 2016 by the housing and the Ministry of Urban and Rural construction approved the establishment 59 prefabricated construction Industrial base (formerly "the National Housing Industrialization Base") to carry on the statistics each enterprise in the transformation business change situation. The data information originates from the official website of the Department of Housing and Construction, and is authentic and authoritative. It is divided into five categories according to the attributes of its prior transformation: (A) construction units, (B) Real estate Development Enterprises, (C) design units, (D) materials (parts) manufacturing enterprises, (E) Other industries, and take the five types of enterprises as the research object of this study. Figure 3 gives the various types of enterprises in the transformation of the number of business volume and its total.

\begin{tabular}{|c|c|c|c|c|c|c|c|}
\hline $\begin{array}{l}\text { Before the } \\
\text { transition }\end{array}$ & $\begin{array}{l}\text { Constructio } \\
\text { n units }\end{array}$ & $\begin{array}{c}\text { Real estate } \\
\text { Developm } \\
\text { ent } \\
\text { Enterprise } \\
\mathrm{s}\end{array}$ & Design & $\begin{array}{c}\text { Materials } \\
\text { (parts) } \\
\text { units manufacturi } \\
\text { ng } \\
\text { enterprises }\end{array}$ & $\begin{array}{c}\text { PC } \\
\text { component } \\
\text { manufactur } \\
\text { er }\end{array}$ & $\begin{array}{c}\text { The whole } \\
\text { industry } \\
\text { chain }\end{array}$ & Total \\
\hline (A) Construction units & 12 & 0 & o & 2 & 1 & 3 & 18 \\
\hline $\begin{array}{l}\text { (B) Real estate } \\
\text { Development Enterprises }\end{array}$ & o & 6 & o & o & 2 & 1 & 9 \\
\hline (C) Design units & o & o & 2 & o & o & o & 2 \\
\hline $\begin{array}{l}\text { (D) Materials (parts) } \\
\text { manufacturing enterprises }\end{array}$ & 1 & o & o & 6 & 7 & 1 & 15 \\
\hline (E) Other industries & 2 & o & o & 6 & 3 & o & 11 \\
\hline
\end{tabular}

Figure 3 Number and total of the five categories of enterprises after transformation

\section{Niche Breadth}

The Simpson niche width measure model of the selected formula (1) is calculated, the results are shown in the figure 4.

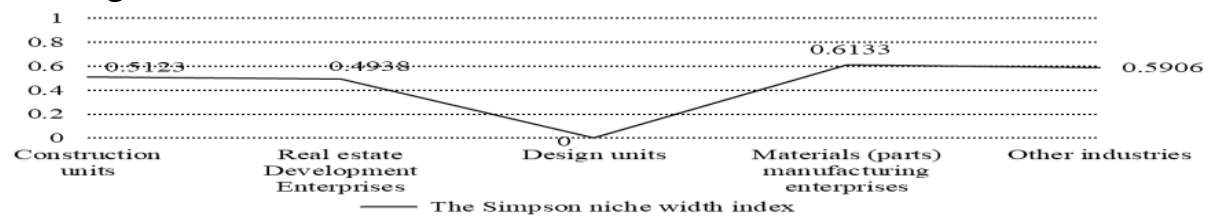

Figure 4. The Simpson niche width index in the transformation of large-type enterprises 


\section{Niche overlap}

In this paper, we select the Pianka and Cowll niche overlap Index formula (2) and give the results of niche overlap index, as shown in figure 5.

\begin{tabular}{|c|c|c|c|c|c|c|}
\hline & $\begin{array}{l}\text { Construction } \\
\text { units }\end{array}$ & $\begin{array}{l}\text { Real estate } \\
\text { Development } \\
\text { Enterprises }\end{array}$ & Design unit & $\begin{array}{c}\text { Materials } \\
\text { (parts) } \\
\text { manufacturin } \\
\text { g enterprises }\end{array}$ & $\begin{array}{c}\text { PC } \\
\text { component } \\
\text { manufacturer }\end{array}$ & $\begin{array}{c}\text { Other } \\
\text { industries }\end{array}$ \\
\hline $\begin{array}{l}\text { Construction units } \\
\text { Real estate }\end{array}$ & 1.000 & & & & & \\
\hline $\begin{array}{c}\text { Development } \\
\text { Enterprises }\end{array}$ & 0.167 & 1.000 & & & & \\
\hline Design units & 0.000 & 0.000 & 1.000 & & & \\
\hline $\begin{array}{c}\text { Materials (parts) } \\
\text { manufacturing } \\
\text { enterprises }\end{array}$ & 0.300 & 0.289 & 0.000 & 1.000 & & \\
\hline $\begin{array}{l}\text { PC component } \\
\text { manufacturer }\end{array}$ & 0.500 & 0.500 & 0.500 & 0.500 & 1.000 & \\
\hline Other industries & 0.382 & 0.256 & 0.000 & 0.773 & 0.500 & 1.000 \\
\hline
\end{tabular}

Figure 5. The niche overlap Index matrix of Cowll and Futuyma after the transformation of large class enterprises

\section{RESULTS AND DISCUSSION}

Niche breadth. The Niche Breadth of the material unit is the widest. Thus, the material production enterprises in the transformation and upgrading process business expansion and resource utilization are relatively balanced. The niche breadth of construction enterprises and real estate development enterprises is relatively low. Looking at the characteristics of business distribution after the transformation of these two enterprises, the proportion of business in their own field is relatively large. The design unit has the lowest niche breadth and is zero. It is explained that the business distribution after the transformation of the design unit is all focused on the design unit's own field.

Niche overlap. After the transformation of enterprises, the niche overlap degree of enterprises and materials production enterprises in other industries is the highest. Thus, the distribution of business types of these two types of enterprises in the process of transformation is similar, they are in a state of both shared resources and fierce competition. The niche overlap degree between PC component manufacturers and other types of enterprises is 0.500 . From this, it can be seen that PC component manufacturers are a major direction of transformation of various types of enterprises. The niche overlap index between construction units, real estate development enterprises and design units is very low. Most of the transformation and upgrading of these three are further expanded in their own field, rarely transformed into other business areas.

In summary, the role transformation trend of different stakeholders in the construction industrialization industry chain is not the same, and the reason for this is that they each assume a different role First of all, real estate developers play a leading role in promoting the development of building industrialization, and they do not have strong technical characteristics, 
its transformation is more of their own corporate philosophy, corporate goals on the transformation Therefore, the traditional real estate developers often transform into a new type of real estate developer with the idea of building industrialization or a comprehensive enterprise with more business in one. Secondly, the role of the construction unit in the industrial chain is the technology provider, the key to the transformation of building industrialization lies in the industrialization construction technology. This transformation is very targeted, and China's industrial construction technology has been relatively mature. As a result, most construction units are at a technical level of transformation and will not change or expand their business. Again, there is little transformation in the design unit. This is because although the design unit is the key link in the construction industry chain, the architectural design industry is still in the auxiliary position of serving the developers in our country, and it rarely affected by the cost of industrial construction and the post construction of building participation. Therefore, the transformation consciousness of the design unit is relatively low in the whole industrial chain. Finally, the niche breadth of the traditional building material supplier is the widest after transformation This is because, with the implementation of building industrialization, the industrial production mode gradually replaces the traditional construction industry, the demand for raw materials is gradually reduced by developers and construction units, and the demand for prefabricated components is gradually increasing. As a result, traditional building materials suppliers that produce construction raw materials have transformed into other types of enterprises in the industrial chain, and have spawned a new kind of stakeholders, That is, PC component manufacturers, which is the traditional building materials suppliers the most concentrated direction of transformation.

\section{CONCLUSION}

This paper introduces the transformation of various stakeholders in the construction industrialization industry chain, and focuses on the transformation of its enterprise nature. It provides a method to measure the transformation trend of enterprises through the enterprise niche theory, which is mapped to the five stakeholders in the building industrialization industry chain. The significance of this paper is to describe the phenomenon of the transformation of construction industrialization related enterprises by quantitative method, and to reveal the causes of this phenomenon. This is of great significance to promote the development of building industrialization.

Key findings of the work. The transformation intensity and trend of various stakeholders in China's industrial and construction industry chain are obviously different. In summary, the transformation business expansion and resource utilization of materials unit are relatively balanced, construction units and real estate developers mainly in their own field of transformation and expansion, and design units rarely exist transformation situation. As far as the transformation trend is concerned, PC component manufacturers are one of the major directions for the transformation business expansion of other related enterprises. 


\section{ACKNOWLEDGEMENTS}

This study was supported by the Chongqing University through the Special Social Science Research Program of the Central Universities Fundamental Research Foundation (Grant No. 106112016CDJSK030006).

\section{REFERENCES}

Baum, J. A. C., and Singh, J. V. (1994). "Organizational Niches and the Dynamics of Organizational Founding." Organization Science, 5(4), 483-501.

Guo, Y., and Xu, X. (2009). "A review of corporate niche research: concepts, measures and strategic applications." Review of Industrial Economics, 08(2), 112-126.

Hannan, M. T., and Freeman, J. (1977). "The Population Ecology of Organizations." American Journal of Sociology, 82(5), 929-964.

Ji, Y., Zhou, X., and Li, X. (2013). "Application of BIM Technology in New Building Industrialization." Construction Economy(8), 14-16.

Li, C. Z., Hong, J., Xue, F., Shen, G. Q., Xu, X., and Mok, M. K. (2016). "Schedule risks in prefabrication housing production in Hong Kong: a social network analysis." Journal of Cleaner Production, 134, 482-494.

$\mathrm{Li} \square$, J., Zhu, J., and Zhu, Q. (2003). "A review on niche theory and niche metrics." Journal of Beijing Forestry University, 2(1), 100-107.

Lu, N., and Lin, Y. (2013). "Competitiveness analysis of top international contractors based on niche theory." Journal of Engineering Management(2), 109-113.

Qian, H. (2005). "Niche,factors interacting and organization evolution." Zhejiang University.

Qian, Y., and Ren, H. (2006). "Research on theCompetitiveRelationship ofEnterprisesBased on Niche Theory." Finance and Trade Research, 17(02), 129-133.

Sun, J., Yu, J., and Deng, X. (2017). "Measurement and Analysis of the Ecological Position of International High-speed Railway Enterprises." Decision making (II)(9).

Xiao, T., Li, Q., Zhen, W., Jin, C., and Wang, Z. (2015). "Discussion on the Development of New Building Industrialization under the Background of Urbanization." China Water Transport, 15(7), 57-58.

Zhai, X., Reed, R., and Mills, A. (2014). "Factors impeding the offsite production of housing construction in China: an investigation of current practice." Construction Management \& Economics, 32(1-2), 40-52.

Zhang, L., and Guo, Y. (2009). "An Empirical Study on the Status of Bank Niche in China." Financial Theory \& Practice(9), 13-17.

Zhang, X., Skitmore, M., and Peng, Y. (2014). "Exploring the challenges to industrialized residential building in China." Habitat International, 41(41), 176-184.

Zhao, z., and Tang, C. (2016). "Measurement and Analysis on Enterprises Niche for International Contractors-An Empirical Study based on the Top 250/225 International Contractors Data." Journal of Beijing Institute of Technology(Social Sciences Edition), $18(1), 62-72$. 